\title{
The 'Social Life' of Conservation: Lessons from Danau Sentarum
}

\author{
Reed Lee Wadley ${ }^{1}$, Carol J. Pierce Colfer ${ }^{2}, \underline{\text { Rona Dennis }}^{2}{ }^{2}$, and $\underline{\text { Julia Aglionby }}^{3}$
}

\begin{abstract}
This article focuses on a team's collaborative conservation experience, beginning in 1991 in Danau Sentarum National Park in West Kalimantan, Indonesia. The experience of three teams is recounted as they worked collaboratively with local Malay and Iban communities to manage the flooded and lowland tropical forest area. Relations between conservation workers and communities are discussed, and social capital among conservation workers is highlighted as another centrally important feature in conservation success. Subsequent involvement of the network of concerned researchers is also described. Central points of the article are 1) that conservation practices are socially embedded, and 2) that a "best practices" approach is inadequate when personal characteristics, experiences, and networks have such long lasting impacts on conservation itself.
\end{abstract}

Key Words: community; conflict; Danau Sentarum; ICDP; Indonesia; networks; trust

\section{INTRODUCTION}

Biodiversity conservation is a human endeavor: initiated by humans, designed by humans, and intended to modify human behavior to achieve a socially desired objective. (Mascia et al. 2003)

The contribution of social science to conservation has tended toward one of two general trajectories. The first involves the study of local resource management/ecological knowledge, and enhancing such practices and knowledge to ensure their compatibility with conservation concerns (e.g., collaborative or comanagement as in Brown 2003 or Brosius et al. 2005).

The second trajectory tests whether the people in question are truly conservative of their resources, sometimes thereby encouraging a preservationism in which local people are seen as a problem to be removed (e.g., Brockington's [2002] “fortress conservation"). This latter trajectory emphasizes conflict over natural resources, i.e., political ecology, (e.g., Nygren 2004). Such work has likewise tended toward bifurcation: from advocacy for local people, designed to provide them with more voice in competition among stakeholders (Li 2007), to the largely academic, which tends to be written in language that makes it somewhat inaccessible to most conservationists (e.g., Tsing 1993, 2005).
Here, instead, we emphasize how conservation management requires management of the social relations surrounding natural resources (Natcher and Hickey 2002, Brechin et al. 2003, Wollenberg et al. 2005). We use 'management' in two ways: as a process to rationalize and/or improve the care, use, and sustainability/conservation of natural resources; and as a process to organize people and their interactions more effectively.

The notion of social capital is useful in developing strategies to manage such social relations (Pretty and Smith 2004). However, conservation researchers have often tried to build social capital among local stakeholders without fully acknowledging our own roles in such processes. We have underestimated our own parts, as conservationists, in the social world from which social capital is built, and thereby left unexamined a key pillar of successful, or unsuccessful, conservation practice.

The human dimensions in conservation practice are often relegated to those elements outlined above, that is, local ecological knowledge/practices, negative human impacts, issues of resource conflict, or building local capacity. However, there is another vitally important dimension: human interaction within conservation practice, the intimate social relationships among people engaged in conservation projects. These have a fundamental role to play in 
the success or failure of conservation programs and thus deserve our attention. Many conservationists and researchers strive for an objectivity that discourages examination of human relations, perhaps in recognition of the impossibility of true objectivity when humans study humans. However, the difficulty of conservation management requires us to make the effort.

Social capital refers to "features of social life networks, norms and trust - that enable participants to act together more effectively to pursue shared objectives" (Putnam 1995:664-665, Pretty and Smith 2004). A focus on the institutional aspects of human sociality may result in an assumption that the actual people involved can be substituted without any change to on-the-ground social relations (e.g., Salafsky et al. 2002). Fukuyama (2005:112) sums this up nicely, referring to,

...the frequently dysfunctional character of "best practice" mentality, where a practice that works in one part of the world is immediately publicized and set up as a model for other parts of the world. Successful programs [often involve] what James Scott (1998) labels metis - the ability to use local knowledge to create local solutions.

We may lose sight of the socially embedded nature of our own human activity when material resources are at issue (Uphoff 1996, Fukuyama 2005, Lowe 2006).

Seixas and Davy (2008:99), in a recent study of successful conservation projects in 2002 and 2004, observed that,

...CBC [community based conservation]
and ICDP [integrated conservation and
development program] initiatives opportu-
nistically evolve in a multi-level world, in
which local communities establish linkages
with people and organizations at different
political levels, across different geographical
scales and for different purposes.

Their study found numerous examples of involvements, such as those described herein for the Danau Sentarum National Park (DSNP) networks, contributing to the success of their cases. In general, we share Seixas and Davy's (2008) conclusion that there is no right "recipe" for good conservation practice, that one needs a varying mix of "ingredients". The six ingredients these authors identify are 1) involvement and commitment of key players, including communities, 2) funding, 3) strong leadership, 4) capacity building, 5) partnership with supportive organizations and government, and 6) economic incentives, including alternative livelihood options. Our discussion will be focused on numbers, 1,4 , and 5 .

Here, we examine the "social life" of conservation, drawing on our collective and long-term experience in DSNP, West Kalimantan, Indonesia. We focus on DSNP teams' relations with local communities and interactions with other conservationists, but we are particularly interested in how the nature of such social relationships affects efforts to enhance conservation outcomes. We see the role of the trust, interpersonal networks, and reciprocity between and among conservation personnel and local stakeholders as under-recognized within the field, yet crucial to conservation success.

\section{STUDY SITE}

DSNP, located in West Kalimantan, Indonesia (Figs. 1 and 2), is an area of interconnected seasonally flooded lakes and forests, with lowland tropical forest in the nearby uplands, constituting a patchwork of forest stages. The altitude is approximately 30-35 m above sea level, with surrounding hills up to $760 \mathrm{~m}$. Daytime temperatures are consistently $26-30^{\circ} \mathrm{C}$, with annual rainfall $3000-4000 \mathrm{~mm}$. The driest months are JulySeptember.

Danau Sentarum Wildlife Reserve was established in 1985 (Giesen 1987), became Indonesia's second Ramsar site in 1994, and was upgraded to a National Park in 1999 (Giesen and Aglionby 2000). Still, most management has been carried out by local communities (Colfer et al. 1999, Dennis et al. 2001, Indriatmoko 2008). The park comprises around $1320 \mathrm{~km}^{2}$ (Whiteman and Aglionby 1997, Wadley et al. 2000), with unclear boundaries and buffer zone. Indriatmoko's 2007 census of DSNP showed a population of 10,300 (Indriatmoko 2010), 93\% of which were Malays, primarily dependent on seasonally variable fisheries; the remainder being mostly Iban swidden agriculturalists.

In 1992, the first project team began formal collaborative management of the reserve, under the Indonesian Agency for the Conservation of Natural 
Fig. 1. Danau Sentarum National Park, West Kalimantan, Indonesia.

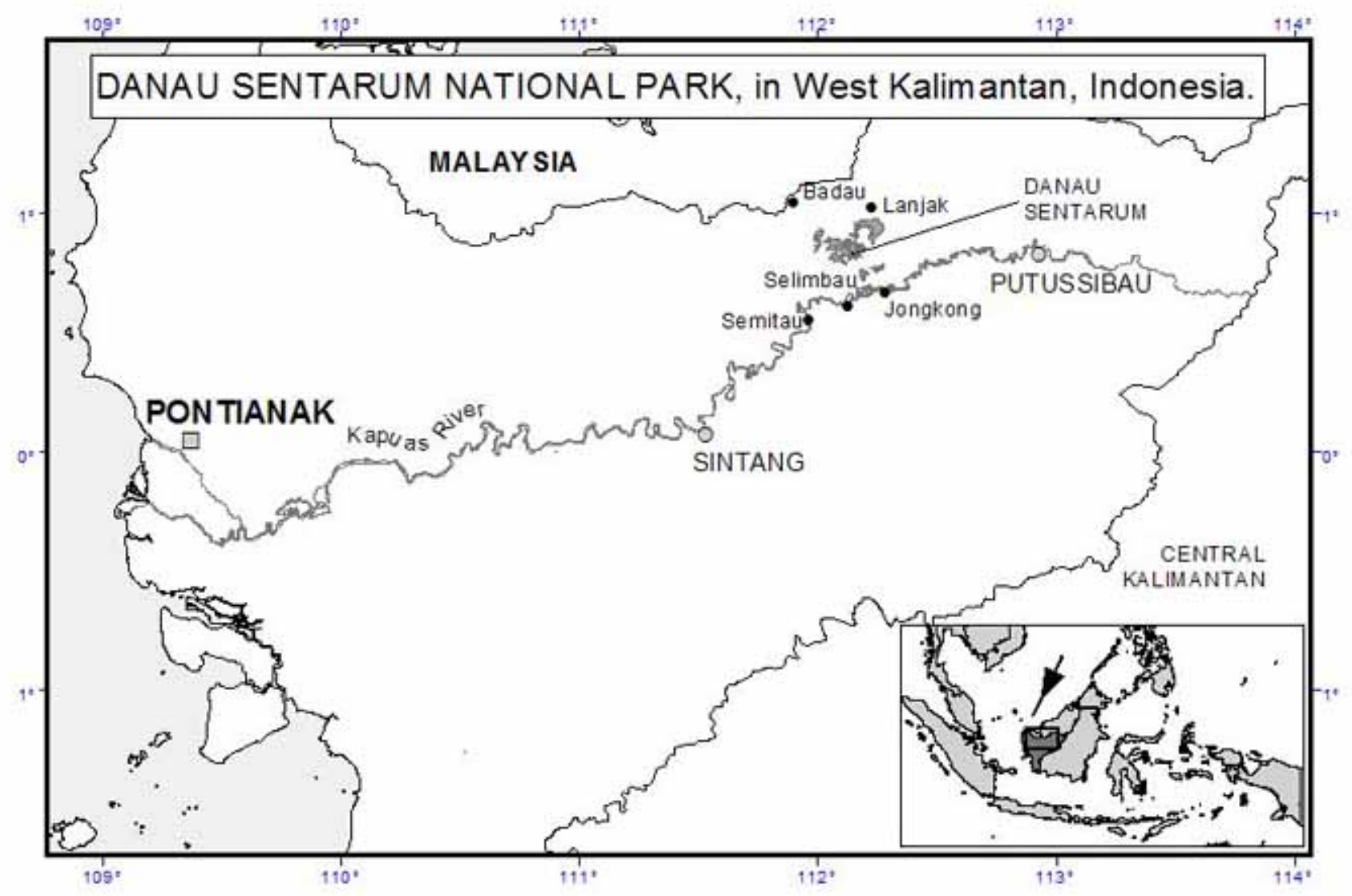

Resources (KSDA) and Asian Wetlands Bureau (AWB), under subcontract to a consulting firm. During the project's five years, three consecutive international teams (Teams 1, 2, and 3) led larger shorter term teams.

The conservation project began with a strong emphasis on collaboration. Team 1, including Wadley, Colfer, and her husband and team leader, Richard Dudley, moved to Danau Sentarum in June 1992, initially encountering real fears from the communities, e.g., that we sought shrimp with diamond eyes, a local virgin to kill and bury under the field center house posts, and to build a bridge over Danau Sentarum, an improbable engineering feat. Working closely with communities, repeatedly explaining our goals and demonstrating our reliability over time, we established a field center, studied the two main local systems, and began comanagement.
Team 2 focused primarily on protection of the area from local communities, spending little time in the field, and emphasizing ecological matters, with little interest in local communities. One member of Team 3 emphasized marketing of alternative income generating opportunities for the community; the other focused on local ecology and a management plan. Aglionby joined as an environmental economist, as Team 2 was leaving. Dennis, the long term Remote Sensing and geographic information system (GIS) advisor, remained with the project throughout. Based in Bogor, she spent considerable mapping time in the field. There were clearly significant differences in perspectives among the three teams, with Team 1 focused on collaborative management and establishing a social baseline and the needed infrastructure, Team 2 on protecting the park from local people, and Team 3 primarily on income generation and establishing an ecological baseline. All authors of this paper shared a strong 
Fig. 2. Some important locations in Danau Sentarum National Park, West Kalmantan, Indonesia.

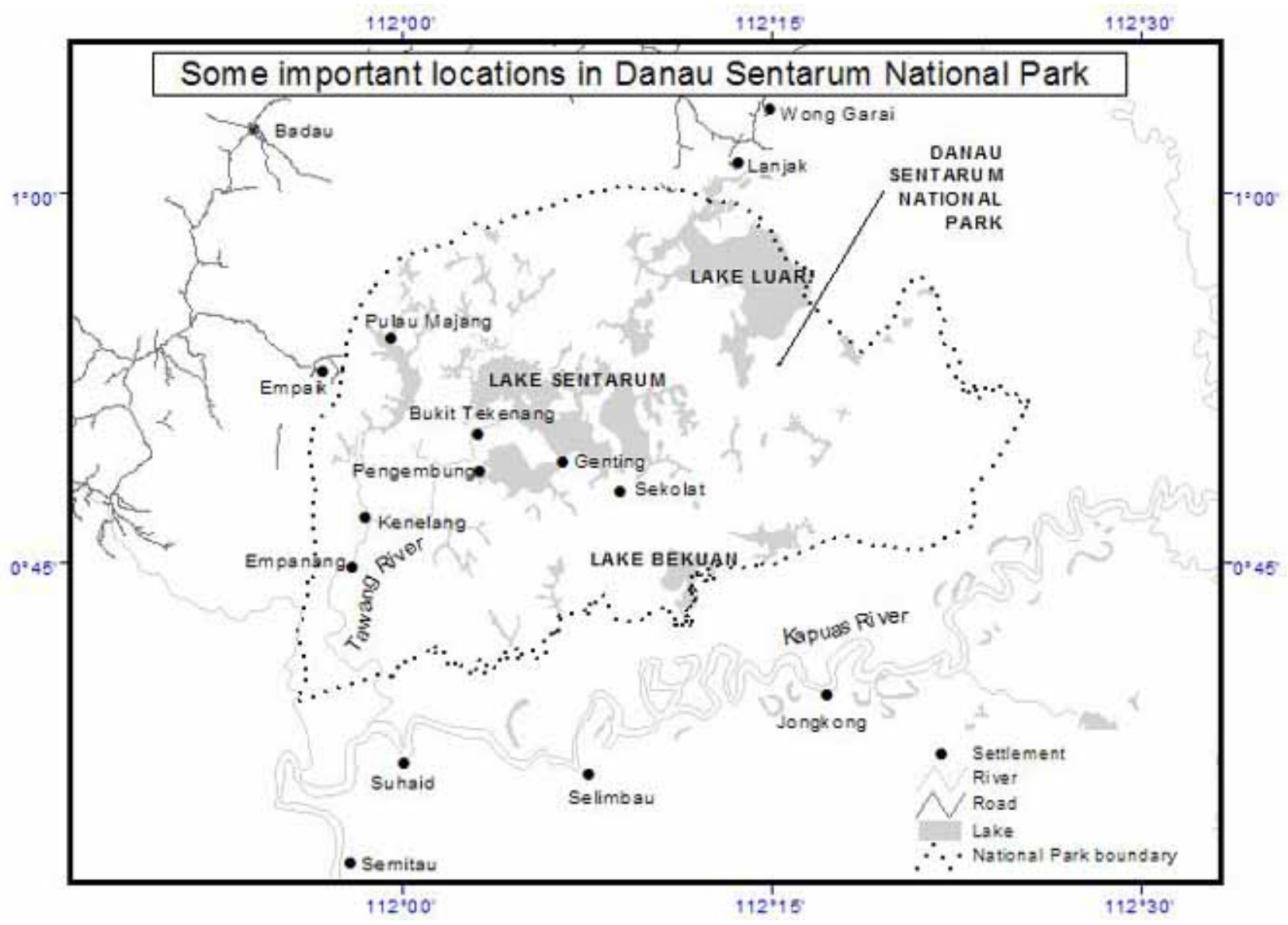

interest in both conservation and local people's well-being.

Indonesia has undergone many changes with implications for conservation, most notably decentralization. The district in which Danau Sentarum is located, Kapuas Hulu, declared itself in 2003 a "Conservation District," spurred initially by NGOs, later in search of carbon credits. In 2007 , the central government funded a management unit and developed a participatory management plan. Now, in 2010, there are more than 20 projects underway in the park (Colfer and Yuliani 2010). Continuing threats include logging, possible dam construction and oil palm development, gold mining, and transmigration schemes (Valentinus et al. 2010).

\section{CONSERVATION TEAMS AND LOCAL PEOPLE}

Below, we consider three significant events pertaining to local resources and territorial claims, i.e., land claims, territorial mapping, and conflicts, that affected relations between conservation teams and local people. We then discuss the day-to-day interactions that more fundamentally produce both problems and enduring links with local communities.

In June 1992, Team 1 and AWB colleagues visited DSNP to choose a field center site. Anxious to avoid territorial conflicts and cognizant of potential negative repercussions for communities of conservation projects, we visited Malay and Iban communities in the reserve core, buffer zone, and beyond, discussing land tenure everywhere. We found no expressed conflicts or claims on lands; the only expressed interest was in fishing. 
A month later, we were invited to a multistakeholder meeting, primarily of Malays, at Selimbau's floating minihotel on the Kapuas River, near the county-level military, police, and government officials' offices. We were amazed to be immediately subjected to a prolonged and vituperative verbal attack, very unusual in Indonesia, by a locally respected Malay man who accused us of trying to steal land that belonged to his family.

Our desire to respect local people's rights, combined with the mandate to build a field center in an unclaimed area, constituted a difficult ethical dilemma. Legally, the central government had the right to build a field center there, despite the fact that communities in Indonesian protected areas typically have overlapping claims we considered legitimate. We explained our point of view, and the group sent us to consult with district officials. On our return, the aggrieved man dropped his claim, apparently willingly, and the stakeholders involved subsequently worked cooperatively and happily with us. Building on this low-key, rational negotiation process, local stakeholders appeared to realize that we were not intent on enforcing national policy at all costs and were seriously interested in both human welfare and effective conservation, a promising beginning for establishing good relations.

Between 1994 and 1997, the project's mapping team, led by Dennis, followed up on the discovery of a sophisticated system of customary land tenure. We conducted discussions about boundaries with local fishing communities and created village sketch maps to understand better local people's use of natural resources. We and the local staff accurately captured the complexity of these boundaries. Mapping identified conflicts between communities, and sometimes led to conflict resolution; some communities physically marked their boundaries; and suspicions sometimes surfaced about project motives, especially in those communities with valuable forests.

In total, we mapped over 85 village work areas (wilayah kerja), and created a GIS. Digitalizing these boundaries, linked with other spatial datasets provided a powerful platform for understanding local land use dynamics. Realizing its sensitivity, we protected the communities' intellectual property rights, refusing to share the data with third parties, i.e., government, industry, NGOs, most researchers. This became even more important during the peak of illegal logging when external entrepreneurs tried to exploit local forests, via communities' de facto ownership.

In 1994, the use of artificial chemical poisons by Dayak communities resulted in a major loss of fish, both wild and caged. I (Aglionby) participated, along with the vice-governor, police, fisheries, and conservation services, in brokering a settlement between Iban and Malays. This high level political intervention helped reach a settlement, with the vice-governor traveling to the reserve for the signing. The agreement was based on customary (adat) law on the premise that it could then be enforced by local communities rather than relying on police intervention, though significant poisonings recurred twice (Yasmi et al. 2007). The project's role as a valued mediator was widely recognized.

Community-project relations evolve over time, in the course of day-to-day interactions. The process of working with communities may alternate between moments of elation and inspiration, dismay and regret. Examples of both are presented below, with emphasis on the more instructive problematic cases.

On the beneficial side, at the beginning, community concerns began to evaporate as we worked with groups to plan monitoring of timber companies, coordinate customary regulations in various microcatchments for better fisheries management, discuss how to limit in-migration during the dry season, and conduct a study of floating gardens as a means to improve poor Malay diets and related poor health (Dudley and Colfer 1993). Such evidence of concern appeared to strengthen our acceptance in the communities.

In 1995, several community members were appointed as honorary rangers, giving conservation workers additional recognized status within their community. In a subsequent socioeconomic rapid appraisal, we (led by Aglionby) uncovered a strong community interest in health centers, schools, and credit. Various activities in the Field Center exposed outsiders to communities and the reserve. All the efforts to engage individuals and build social capital, i.e., meetings, conferences, a library, sports days, dances, TV viewing, proved worthwhile. 
However, these positive interactions were interspersed with more disruptive ones. We found that small personal mistakes can have long-term and serious consequences. The simplest and probably most common kinds of disruptions between conservation workers and communities are based on everyday human foibles, i.e., fatigue, irritation, impatience. In August 1992, for instance, I (Colfer) wanted to accompany a local Malay woman on her agricultural rounds, to get a better sense of women's views. My assistant wanted to accompany me. Fearing that the woman would be inhibited if a local man were present, I convinced him to stay behind. Things were progressing well, when suddenly the assistant and several other men appeared, anxious to help. I was hot and tired and very disappointed by their untimely arrival. When it became clear that the men were really going to take over the conversation as predicted, I stormed off in an angry huff. Although I knew this was totally inappropriate, I was just too hot, tired, and irritated. The woman with whom I'd been building a viable relationship avoided me for the remainder of my stay there, considering me just too unpredictable and rude. The woman's distrust, as a respected community member, surely did nothing to improve the project's standing in the community.

In 1993 following our (Team 1's) departure, new consultants were appointed. Although we had made considerable strides in overcoming local people's fears and developing the project, we had only been able to work directly in five villages, including Wadley's ethnographic work. Team 2 largely ignored communities, not considering the people suitable as conservation managers. By April 1994, when I (Aglionby) arrived, significant levels of distrust regarding the project had built up. I visited all villages within the reserve and the proposed extension, undertook an appraisal of community use of resources, and mapped the territories they managed.

I found a resurgence of rumors, e.g., that the project was digging out the hill behind the Field Center to find gold and to fill the gap with skulls. Communities wanted nothing to do with the project. This distrust came to a head at a workshop in Pontianak attended by DSNP village heads, when a document was distributed that accidentally described the Iban as "savage." Iban leaders met with me privately and demanded a trial, otherwise there would be killings. The Indonesian civil servants took the threat seriously, convening a customary (adat) court that afternoon. We apologized profusely, a sentence was handed down, and the fine was paid. Once settled, no further mention of this incident was made, in accordance with Iban tradition.

\section{SOCIAL CAPITAL AMONG CONSERVATIONISTS}

Although relations between communities and conservation workers are important, the interactions among conservation workers have received even less attention in conservation efforts. Here, we show how social capital among conservation workers, an inherently variable and unpredictable element in social life, can affect conservation success. We begin with a story about fatigue and miscommunication, then address trust, administrative constraints, disciplinary differences, and capacity building.

Although the project plan was to involve eight Indonesian civil servants in DSNP management, less than a person per month had materialized. KSDA could not persuade its personnel to relocate to this remote location where education, health care, professional advancement, and creature comforts were in short supply. We (Team 1) supplemented our own labor with that of speedboat drivers and community members. This strategy, although undertaken by necessity, proved useful in capacity building, for each project team, in terms of strengthened knowledge of local realities and ties with local people, and for our local partners'.

Nine months into the project, the Field Center had finally been built and we had recruited several young, enthusiastic Indonesian researchers who were hard at work. One night, the team leader lay in his bunk (Team 1 lived on a 10m 'motor,' a boat) tired from a long day, waiting for the cessation of the generator, which would allow him to drift off to sleep. Nine o'clock passed, the agreed witching hour, and the noise continued. After another half hour of exhaustion and frustration, unable to escape this loud, insistent clamor a few meters from his head, he got out of bed, yanked on his clothes, and stormed up to the Field Center. The researchers were all there, talking, working, laughing. In a fit of pique, he maligned them for interfering with his sleep, stormed back down to the generator and abruptly turned it off. 
The next morning brought disaster. Two of the new arrivals had been working and found themselves suddenly immersed in darkness when the generator went off. Feeling a serious affront to their dignity, they were ready to pack their bags and leave immediately. I (Colfer) wrote:

\section{At this point, the poignancy of the situation overwhelmed me. We finally had the co- workers we had wanted, and these two were unusually fine people. But difficulties caused by fatigue and cross-cultural miscommunication were threatening it all... The last thing we wanted to do was drive them away, by accident. My tears seemed to convince them that we actually were genuinely contrite, and they began slowly to forgive us (2006:109).}

This kind of experience, so common in international conservation efforts, genuinely endangered the conservation effort through the near-loss of colleagues with crucial skills and knowledge. Demonstrating our regret was essential in this case. Fortunately, both volunteers overcame their anger and have continued to work on conservation issues, one with KSDA.

Trust is an integral part of the social capital we consider crucial for effective conservation actions (cf. Berkes 2007b). It is central to effective collaboration and has serious effects on team members' motivations. It can also be destroyed much more easily than it can be established.

We (Team 1) entered Danau Sentarum with great enthusiasm about community involvement in conservation and the opportunity to work with an NGO, which we trusted would be sincerely motivated to enhance conservation. This trust quickly began to erode. The project site was 16 hours of tough travel by car and speedboat from Pontianak, the nearest source of money and communication with the home office. We would develop a request, indicate the money needed, and ask that it be sent in a month. The Bogor office would agree, but a month later, none, or half of the money would be there. We made commitments and hired people on the basis of the planned budget. When the money did not come, we repeatedly used personal funds to make up the difference, in recognition of local poverty.

Despite repeated assurances that our own salaries were being paid, in December we discovered that the only payment sent had gone out five months previously, in July. We had been working, and in fact funding parts of the project, pro bono since then.

Month followed month and our trust in our employers eroded further. We threatened to quit. Promises of improvement were made. In April, I (Colfer) became ill and returned to the U.S. Still there were no administrative improvements. Finally, we reluctantly submitted our resignations, deeply worried about ultimate conservation outcomes and community enthusiasm should a "fines and fences" approach follow, a concern that proved justified.

In the previous example the loss of trust resulted in the loss of the two central conservation workers. However, administrative constraints alone can also be a stumbling block. The NGO, AWB was subcontracted by a for-profit consulting firm. Relations between these two entities were not cordial, resulting in 1) our being denied essential support while the two Java-based institutions bickered, and 2) our inaccurately being suspected of the NGO's lax accounting procedures, resulting in impossible requests like "mileage" for speedboat travel, receipts from illiterates, all of which detracted from progress on conservation.

Relations between project teams and the national park authorities also held potential landmines. The first KSDA director helped us work through the bureaucracy, avoiding costly mistakes, such as the near labeling of the Field Center as a "building", which would have involved the Public Works Department, a notably corrupt institution in those days. By calling it a "field post," we avoided paying expensive additional charges.

The second KSDA director was a bright young scientist who had had a series of run-ins with other international experts. He initially took a very aggressive stance, demanding to know what we had accomplished in Team 1's first four months. We complied, mentioning also the problems obtaining funds, reminding him gently about the promise of eight KSDA team members.

As he realized that we were sincerely trying to accomplish project goals under difficult conditions, he became a serious advocate, including coming to the field and sending some of his junior staff to work there. Although we worked with him for less than a year, the developed trust remained, yielding further collaboration. 
Another international member of the team had a less successful relationship with him. A foreign wildlife volunteer wore shorts and sandals habitually, which is fine in the field, but inappropriate in Indonesian offices at that time. KSDA displeasure was compounded by the volunteer's inadvertently using the project car once when a senior KSDA official wanted it. The young man was denied permission to stay in the field. Lack of awareness of cultural norms lost us a valuable and much needed human resource.

Disciplinary differences represent common problems among conservation workers. Team 1 , for instance, included two anthropologists (Colfer and Wadley) and a fisheries biologist as team leader; the Bogor-based, AWB project coordinator was an ecologist, all sharing responsibility for project direction. We all recognized the need for both human and environmental welfare, but there were predictable differences in priorities: anthropologists prioritized people's needs, biological scientists had environmental concerns. Although resulting only in creative tensions in DSNP, disciplinary disagreements can be extremely disruptive.

The genuine concern for local people evidenced by numerous researchers and NGO activists, beyond the examples provided here, strengthened some local individuals' long-term commitments to conservation and resulted in effective capacity building. One group of local project employees formed their own NGO (Riak Bumi, http://www.ria kbumi.or.id/content/view/105/133/). Another consults for Flora and Fauna International. A community leader from Pulau Majang maintained his concerns for nearly two decades, beginning on a recent series of "shared learning" meetings on collaborative conservation throughout Indonesia, stopped only by a stroke in 2010. Many such examples exist.

\section{CONCLUSIONS AND FOLLOW-UP ACTION}

The formal Department for International Development (DFID)-KSDA project to manage Danau Sentarum only lasted five years (1992-1997), but low level inputs continued in subsequent years. Local actors, Indonesian researchers and bureaucrats, and international researchers have retained their commitment and enthusiasm for DSNP conservation and for people's well-being.
Riak Bumi's continued involvement is one indicator that conservation concerns remain alive, that Danau Sentarum is more than a paper park. Others include routine contributions to keep a community newsletter going; five year pledges to contribute funds to Riak Bumi; a popularized book (C. J. P. Colfer 2006, self-published through lulu.com) about the area, with minimal royalties for Riak Bumi; creation and showing of Center for International Forestry Research (CIFOR) films, "Cerita Pak Burung" and "Danau Sentarum National Park: The Abandoned Paradise," to national and international audiences (http://www.cifor.cgiar.org/livesinforests/ ref/materials/films/index.htm).

A group of early researchers produced a special issue of Borneo Research Bulletin devoted to DSNP (Volume 31, 2000), with another special issue coming in 2010. Research has been conducted on hunting (Wadley et al. 1997); illegal logging (Wadley 2000, Wadley and Eilenberg 2005); fires (Harwell 2000, Dennis et al. 2005); criteria and indicators (Colfer and Byron 2001); land cover change (Dennis et al. 2001); and more. New and returning researchers work with communities, conduct ecological studies, train villagers, and coordinate multistakeholder management planning (e.g., Indriatmoko et al. 2007, Yasmi et al. 2007, Indriatmoko 2008, Mulyana et al. 2008, Yuliani et al. 2008, L. B. Prasetyo, personal communication, E. L. Yuliani, H. Adnan, and Y. Indriatmoko, personal communication).

The vibrancy of this continued involvement builds on relationships of trust, reciprocity, and sociability, with local communities, but perhaps more significantly, among those working on conservation. We became friends, linked together by common concerns. We grew to love the area and its people and thus retain a commitment to work toward protecting it, for the people who live there now, for the generations to come, and for the human race as a whole. We continue to draw others into this network of concerned researchers, students, activists, and officials.

Converting this kind of informal but powerful network into a set of "best practices" seems unrealistic. There is growing evidence of the significance of both individual action and multilevel linkages in successful collective action and conservation. Krishna (2002) quantitatively examined social capital's role in development in 69 Indian villages, concluding that although social 
capital played a significant role, agents to link communities with outside sources and actors were more important (see also Uphoff 1996). Kubo (2009) examined three cases of community forestry in Asia, similarly concluding that personal agency was the most critical. Seixas and Davy's (2008) findings discussed earlier implicitly acknowledge such agency as well.

Simply recognizing the long lasting power and significant impacts of personal connections among conservation workers could go a long way toward better conservation practice. We, conservation project personnel, should be strengthening our social capital with other stakeholders who can sustain long-term initiatives.

Although there continue to be threats to DSNP, i.e., talk of dams, oil palm, transmigration, and actual logging and population growth, the park has not been destroyed. Despite the persistence of these threats, the level of uncontrolled logging has declined, the dam has not been built, transmigration fears have not been realized, though some oil palm development has occurred since this article was first drafted (see Yuliani et al. 2010, in press). The capabilities and commitments of local communities and bureaucrats continue to be strengthened through collaborative efforts in and around the park and through their participation in fora like the Forest Governance and Learning Groups (http://www.iied. org/natural-resources/key-issues/forestry/forestgovernance-learning-group) and the "shared learning" workshops, similar to Berkes' "learning networks" (2007a, 2009). Without continued involvement by outsiders and committed locals, it seems clear that DSNP would have suffered more dramatic damage than it has.

Responses to this article can be read online at: http://www.ecologyandsociety.org/voll5/iss4/art39/ responses/

\section{Acknowledgments:}

Reed Wadley, who initially envisioned this paper and wrote the first draft, died prematurely of cancer in June 2008. Special thanks go to Emily Harwell, Terry Sunderland, and Cam Webb for their reviews of earlier versions of this paper. We also thank our employers and the people of Danau Sentarum
National Park and its surroundings for their patience with our efforts to institute collaborative management of local forests, waters, and animals. Our forthrightness in this article is intended to improve conservation practice, rather than to offend; we apologize for any possible dismay our analysis may engender.

\section{LITERATURE CITED}

Berkes, F. 2007a. Adaptive co-management and complexity: exploring the many faces of comanagement. Pages 19-37 in D. Armitage, F. Berkes, and N. Doubleday, editors. Adaptive comanagement: collaboration, learning, and multilevel governance. University of British Columbia Press, Vancouver, British Columbia, Canada.

Berkes, F. 2007b. Community-based conservation in a globalized world. Proceedings of the National Academy of Sciences 104(39):15188-15193. [online] URL: http://www.pnas.org/content/104/39 /15188.full.pdf+html.

Berkes, F. 2009. Evolution of co-management: role of knowledge generation, bridging organizations and social learning. Journal of Environmental Management 90:1692-1702.

Brechin, S., P. R. Wilshusen, C. L. Fortwangler, and P. C. West, editors. 2003. Contested nature: promoting international biodiversity with social justice in the twenty-first century. State University Press of New York, Albany, New York, USA.

Brockington, D. 2002. Fortress conservation: the preservation of the Mkomazi Game Reserve Tanzania. The International African Institute, Indiana University Press, and Mkuku Na Nyota, Oxford, UK, Bloomington, Indiana, USA, Dar es Salaam, Tanzania.

Brosius, J. P., A. L. Tsing, and C. Zerner. 2005. Communities and conservation: histories and politics of community-based natural resource management. Altamira Press, Blue Ridge Summit, Pennsylvania, USA.

Brown, K. 2003. Three challenges for a real peoplecentred conservation. Global Ecology and Biogeography 12:89-92. 
Colfer, C. J. P., and Y. Byron, editors. 2001. People managing forests: the links between human well-being and sustainability. Resources for the Future/Center for International Forestry Research, Washington, D.C., USA. [online] URL: http://www .cifor.cgiar.org/nc/online-library/browse/view-publication/ publication/666.html.

Colfer, C. J. P., R. L. Wadley, and P. Venkateswarlu. 1999. Understanding local people's use of time: a precondition for good comanagement. Environmental Conservation 26:41-52.

Colfer, C. J. P., and E. L. Yuliani. 2010. Introduction. Borneo Research Bulletin (Special Issue on Danau Sentarum) 41, in press.

Dennis, R., C. J. P. Colfer, and A. Puntodewo. 2001. Forest cover change analysis as a proxy: sustainability assessment using remote Sensing and GIS in West Kalimantan, Indonesia. Pages 262-387 in C. J. P. Colfer and Y. Byron, editors. People managing forests: the links between human wellbeing and sustainability. Resources for the Future/ Center for International Forestry Research, Washington, D.C., USA.

Dennis, R., J. Mayer, G. B. Applegate, U. Chokkalingam, C. J. P. Colfer, L. Kurniawan, H. Lachowski, P. Maus, R. P. Permana, Y. Ruchait, F. Stolle, S. Suyanto, and T. Tomich. 2005. Fire, people and pixels: linking social science and remote sensing to understanding underlying causes and impacts of fires in Indonesia. Human Ecology 33 (4):465-504.

Dudley, R. G., and C. J. P. Colfer, editors. 1993. Conservation sub-project quarterly report and attachments. Asian Wetlands Bureau (Indonesia Tropical Forestry Management Project), Bogor, Indonesia.

Fukuyama, F. 2005. State-building: governance and world order in the twenty-first century. Profile Books, London, UK.

Giesen, W. 1987. Danau Sentarum Wildlife Reserve: inventory, ecology and management guidelines. WWF Report to Directorate of Forest Protection and Nature Conservation (PHPA), Bogor, Indonesia.
Giesen, W., and J. Aglionby. 2000. Introduction to Danau Sentarum National Park, West Kalimantan. Borneo Research Bulletin 31:5-28. [online] URL: http://www.thefreelibrary.com/Introduction+to+Danau+ Sentarum+National+Park\%2c+West+Kalimantan\% 2c...-a093827516.

Harwell, E. 2000. Remote sensibilities: discourses of technology and the making of Indonesia's natural disaster, 1997-98. Development and Change 31 (1):307-340.

Indriatmoko, Y. 2008. Mengubah air menjadi api: upaya masyarakat rumah panjang Sungai Pelaik membuat pembangkit listrik tenaga mikro-hidro [Converting water into electricity: efforts of the Sungai Pelaik longhouse to generate micro-hydro electrical power]. in Mendorong konservasi yang bermanfaat bagi masyarakat lokal [Promoting Conservation Schemes that Benefit Local People] CIFOR-Riak Bumi Newsletter 3. [online] URL: ht tp://www.cifor.cgiar.org/publications/pdf files/research/ governance/TNDNews3.pdf.

Indriatmoko, Y. 2010. Rapid human population growth and its impacts on Danau Sentarum. Borneo Research Bulletin (Special Issue on Danau Sentarum) 41, in press.

Indriatmoko, Y., L. Yuliani, Y. Tarigan, F. Gaban, F. Maulana, D. W. Munggoro, D. Lopulalan, and H. Adnan, editors. 2007. Dari desa ke desa: dinamika gender dan pengeloalaan kekayaan alam [From village to village: gender dynamics and the management of natural resources]. Center for International Forestry Research, Bogor, Indonesia. [online] URL: http://www.cifor.cgiar.org/publications/ pdf files/books/BIndriatmoko0701.pdf.

Krishna, A. 2002. Active social capital. Columbia University Press, New York, New York, USA.

Kubo, H. 2009. Incorporating agency perspective into community forestry analysis. Small-scale Forestry 8:(3)305-321.

Li, T. M. 2007. The will to improve: governmentality, development and the practice of politics. Duke University Press, Durham, North Carolina, USA.

Lowe, C. 2006. Wild profusion: biodiversity conservation in an Indonesian Archipelago. 
Princeton University Press, Princeton, New Jersey, USA.

Mascia, M. B., J. P. Brosius, T. A. Dobson, B. C. Forbes, L. Horowitz, M. McKean, and Nancy J. Turner. 2003. Editorial - conservation and the social sciences. Conservation Biology 17(3):649-650.

Mulyana, A., H. Adnan, Y. Indriatmoko, A. Priyono, and M. Moeliono. 2008. Belajar sambil mengajar: menghadapi perubahan sosial untuk pengelolaan sumber daya alam [Studying while teaching: confronting social change for natural resource management] Center for International Forestry Research, Bogor, Indonesia. http://www.c ifor.cgiar.org/publications/pdf files/Books/ BMulyana0701.pdf

Natcher, D. C., and C. G. Hickey. 2002. Putting the community back into community-based resource management: a criteria and indicators approach to sustainability. Human Organization 61 (4):350-363.

Nygren, A. 2004. Contested lands and incompatible images: the political ecology of struggles over resources in Nicaragua's Indo-Maiz Reserve. Society and Natural Resources 17(3):189-205.

Pretty, J., and D. Smith. 2004. Social capital in biodiversity conservation and management. Conservation Biology 18:631-638.

Putnam, R. D. 1995. Tuning in, tuning out: the strange disappearance of social capital in America. Political Science and Politics 28(4):664-683.

Salafsky, N., R. Margoluis, K. H. Redford, and J. G. Robinson. 2002. Improving the practice of conservation: a conceptual framework and research agenda for conservation science. Conservation Biology 16 (6):1469-1479.

Scott, J. C. 1998. Seeing like a state: how certain schemes to improve the human condition have failed. Yale University Press, New Haven, Connecticut, USA.

Seixas, C.S., and B. Davy. 2008. Self-organization in integrated conservation and development initiatives. International Journal of the Commons 2 (1):99-125. [online] URL: http://www.thecommons journal.org/index.php/ijc/article/view/24/20.
Tsing, A. L. 1993. In the realm of the diamond queen. Princeton University Press, Princeton, New Jersey, USA.

Tsing, A. L. 2005. Friction: an ethnography of global connection. Princeton University Press, Princeton, New Jersey, USA.

Uphoff, N. 1996. Learning from Gal Oya: possibilities for participatory development and post-Newtonian social science. Intermediate Technology Publications, London, UK.

Valentinus, H., L. Yuliani, and Y. Indriatmoko. 2010. Interacting threats and challenges in protecting Danau Sentarum. Borneo Research Bulletin (Special Issue on Danau Sentarum) 41, in press.

Wadley, R. L. 2000. Community cooperatives, "illegal" logging and regional autonomy: an ACM field report from Kapuas Hulu, West Kalimantan, Indonesia. Center for International Forestry Research, Bogor, Indonesia.

Wadley, R. L., C. J. P. Colfer, and I. Hood. 1997. Hunting primates and managing forests: the case of Iban forest farmers in Indonesian Borneo. Human Ecology 25(2):243-271.

Wadley, R. L., R. Dennis, E. Meijaard, A. Erman, V. Heri, and W. Giesen. 2000. After the conservation project: potential tools for conservation work among mobile peoples. Nomadic Peoples 7 (1):52-73.

Wadley, R. L., and M. Eilenberg. 2005. Autonomy, identity, and "illegal" logging in the borderland of West Kalimantan, Indonesia. The Asia Pacific Journal of Anthropology 6:(1)19-34.

Whiteman, A., and J. Aglionby. 1997. The utilisation of socio-economic data for conservation management planning: a case study from Danau Sentarum Wildlife Reserve in West Kalimantan, Indonesia. Commonwealth Forestry Review 76(4).

Wollenberg, E., J.Anderson, and C. Lopez. 2005. Though all things differ: pluralism as a basis for cooperation in forests. Center for International Forestry Research, Bogor, Indonesia.

Yasmi, Y., C. J. P. Colfer, L. Yuliani, Y. Indriatmoko, and V. Heri. 2007. Conflict 
management approaches under unclear boundaries of the commons: experiences from Danau Sentarum National Park, Indonesia. International Forestry Review 9(2):597-609.

Yuliani, E. L., Y. Indriatmoko, V. Heri, S. Ernawati, L. B. Prasetyo, and M. S. Zul. 2008. Promoting good governance in managing Danau Sentarum National Park through adaptive collaborative management approach. Pages 191-194 in B. Manos and J. Papathanasiou, editors. Governance and ecosystems management for conservation of biodiversity. Gemconbio Project, EU and Aristotle University of Thessaloniki, Thessaloniki, Greece.

Yuliani, E. L., Y. Indriatmoko, M. A. Salim, I. Z. Farid, M. Muhajir, L. B. Prasetyo, and V. Heri. 2010. Biofuel policies and their impacts on local people and biodiversity: a case study from Danau Sentarum. Borneo Research Bulletin (Special Issue on Danau Sentarum) 41, in press. 